\title{
Arrangement of Obligation to Distribute Salary from Ex-Husband Who Works as Civil Servant to Ex-Wife after Divorce
}

\author{
Supadi*1 Thohir Luth ${ }^{2} \quad$ Iwan Permadi $^{2}$ dan Imam Kuswahyono ${ }^{2}$ \\ 1.Postgraduate Program in Law, Faculty of Law, Brawijaya University, Malang - Indonesia \\ 2.Lecturer of Postgraduate Program in Law, Universitas Brawijaya, Indonesia
}

\begin{abstract}
In Indonesia, the obligation to distribute salary from ex-husband who works as civil servant to ex-wife after divorce until she gets married again, is considered unfair and discriminatory. If the divorce occurs at the behest of the husband who works as a civil servant, there is an obligation to distribute salary with his ex-wife until she gets married again. The objective of this study is to examine and discover the concept of reconstruction in regulating the obligation to distribute salary from ex-husband who works as civil servant to ex-wife after justice-based divorce. This is a normative study which will examine legislation in a coherent rule of law as a positive norm that applies at a specific time as a product of a certain power. The results of this study include: 1) if the divorce occurs at the behest of the civil servant husband, he is obliged to provide livelihood costs to the ex-wife according to his ability which are paid when the decision obtains permanent legal force; meanwhile, a Muslim civil servant husband is obliged to provide nafkah mut'ah (a form of monetary gift or consolation) that includes the cost of livelihood to the ex-wife and nafkah iddah (living expense for certain period of waiting) at the witnessing of the divorce pledge in accordance with his ability, 2) if the divorce occurs at the behest of the wife, the husband is not obliged to give a living expense to the ex-wife.
\end{abstract}

Keywords: Civil Servant, Salary, Divorce

DOI: $10.7176 / \mathrm{JLPG} / 85-08$

Publication date:May $31^{\text {st }} 2019$

\section{Introduction}

Marriage is an inner and outer bond between a man and a woman as a husband and wife with the aim of forming a happy and eternal family based on the One Supreme God. ${ }^{1}$

Marriage is one of the most important aspects in human life and even becomes a basic demand for every normal human being. Without marriage, a person's life will become imperfect and violate his/her nature, because Allah SWT has created His creatures in pairs.

Moreover, the purpose and aim of marriage is to form a sakinah (a peaceful atmosphere that surrounds the household of the couple, in which each party carries out the commands of Allah SWT diligently, mutual respect and mutual tolerance), mawaddah (mutual love and support), wa rahmah family (descendants of a healthy and full of blessings from Allah SWT as well as as an outpouring of love and affection from their husbands, wives, and children), ${ }^{2}$ at the same time to give birth to offspring and carry out devotion to Allah SWT. Thus, marriage is a religious bond since the legal effect is to bind men and women in an inner and outer bond as husband and wife with a sacred and noble purpose based on the One Supreme God. It is closely related to religion or spirituality, so marriage does not only have body or physical elements, but also soul or spiritual elements.

Contrary to the above legal issues, the legal provisions, governing the obligation to distribute salary from exhusband who works as civil servant to ex-wife after divorce until she gets married again, cause various problems. It covers philosophical problems, theoretical problems, juridical problems and sociological problems.

Philosophical problems include fundamental philosophical issues, namely the achievement of legal objectives. The main legal objective is to realize justice. Justice is the basis of the law purposes which must be put into all dimensions of a law. Satjipto Rahardjo argues that something cannot be called a law if it does not provide justice. Law actually aims to realize a sense of justice. To achieve these objectives the law must be fulfilled and realized to the fullest. ${ }^{3}$

Related to this matter, provisions, regarding the obligation to distribute salary from ex-husband who works as civil servant to ex-wife after divorce until she gets married again, is considered unfair and discriminatory. The reason is that if the divorce occurs at the behest of the husband who works as civil servant, there is an obligation to distribute salary with his ex-wife until she gets married again. Meanwhile, if the divorce occurs at the behest of the husband who works not as civil servant, he is only obliged to give proper nafkah mut'ah to his ex-wife in the

\footnotetext{
${ }^{1}$ Association of Laws and Regulations concerning Religious Court, (Jakarta: Supreme Court of the Republic of Indonesia, Directorate General of Religious Court, 2010), page 392.

${ }^{2}$ Editorial Board of the Encyclopedia of Islam, Encyclopedia of Islam, (Jakarta, Ichtiar Baru Van Hoeve, 1997), 4th print, part 4, page 1330.

${ }^{3}$ Satjipto Rahardjo, Law Enforcement: A Sociological Review, (Yogyakarta: Genta Publishing, 2009), page 14.
} 
form of money or goods except qobla al dukhul (before intercourse) with the ex-wife and provide nafkah (living expenses), maskan (place of residence) and kiswah (clothing) to the ex-wife during the iddah (a period of waiting) unless the ex-wife has been given talaq ba'in or that she is nusyuz (disobedient) and is not pregnant, and pay off the dowry that is still owed fully, and pay it off half if it is qobla al dukhul.

The legal consequences, regarding the conflict of norm between the norms contained in Article 8 of Government Regulation No. 10 of 1983 jo. Government Regulation No. 45 of 1990 and Islamic Law, cause different treatment before the law/discrimination so that it leads to injustice between ex-husband who works as civil servant and those who works not as civil servant.

Based on the description of the background of the above problem, the subject matter examined and reviewed in this paper is about the reconstruction of the arrangement of obligation to distribute salary from ex-husband who works as civil servant to ex-wife after divorce? The objective of this study is to examine and discover the concept of reconstruction of the arrangement of obligation to distribute salary from ex-husband who works as civil servant to ex-wife after justice-based divorce.

\section{Research Method}

\subsection{Research Design}

This is a normative study which will examine legislation in a coherent rule of law as a positive norm that applies at a specific time as a product of a certain power. ${ }^{1}$

Normative legal research is a type of research that is commonly conducted in the development of legal science in the western world which is commonly called legal doctrine (rechts dogmatiek). Mochtar Kusumaatmaja and Koesno called it the Positive Law, Philipus Hadjon called it the Dogmatic Law, and H. Ph. Visser't Hooft called it the Practical Law. ${ }^{2}$

\subsection{Research Approach}

This study uses 4 (four) kinds of approaches which include philosophical approach, statute approach, historical approach, and case approach. The use of these four approaches is intended so that one approach to the other approaches can complement and enrich each other in analyzing the legal cases faced. According to Enid Champbell, one approach is not sufficient to analyze many cases. ${ }^{3}$

\subsection{Legal Materials}

The source of legal material in this study consists of primary, secondary and tertiary legal materials.

\subsection{Data Collection Technique of the Legal Materials}

The data collection technique of the legal material were carried out through library research which includes: inventory of legislation relating to the problem under study, research on doctrine (opinions of legal experts), concepts, legal principles relating to this research obtained from books literature, judge decisions, and search for legal materials through the internet network or website as well as various legal seminars.

\subsection{Legal Material Analysis and Interpretation Techniques}

The analysis in this study will provide prescription4 about the justification of the current legal construction qualifications related to the obligation to distribute salary from ex-husband who works as civil servant to ex-wife after divorce and the reconstruction of arrangements of the obligation to distribute salary from ex-husband who works as civil servant to ex-wife after justice-based divorce.

This study also uses a qualitative juridical analysis method. ${ }^{5}$ Thus, this study will analyze prescriptively and constructively the primary, secondary and tertiary legal materials in their entirety, deeply and thoroughly.

The analysis can provide significant meaning to the analysis of legal material that can explain the pattern of description and look for relationships between dimensions. ${ }^{6}$ Prescription, regarding justice, construction and

\footnotetext{
${ }^{1}$ Soetandyao Wignyosubroto, An Introduction to the Discussion on the Development of Legal Research in Long-Term Development Phase II, (Jakarta: National Law Development Agency of the Department of Justice), page 5.

${ }^{2}$ Bernard Arief Sidarta, Normative Legal Research: Philosophical and Documentary Research Analysis, in Legal Research Book: Constellation and Reflection, (Jakarta, Yayasan Obor Indonesia, 2009), page 142.

${ }^{3}$ Enid Champbell, et al, Legal Research, (Sydney: The Law Book Company Ltd., 1996), page 274.

${ }^{4}$ Peter Mahmud Marzuki, Legal Research, (Jakarta: Prenada Media, 2008), page 206, who stated that "legal research provides prescriptions about what should be essential from legal research since for this reason the research is carried out; for the purposes of legal practice as well as for academic writing, the prescription given determines the value of the research".

${ }^{5}$ Maria SW. Sumardjono, Guidelines for Making Research Proposals: A Basic Guide, (Jakarta: Gramedia Pustaka Utama, 2001), page 10, who mentioned that "normative legal research that uses secondary data, the research is generally descriptive or descriptive-explorative, and the analysis is qualitative; i.e. a method of descriptive data analysis that refers to a particular problem and is associated with the opinions of legal experts and based on applicable laws and regulations".

${ }^{6}$ Moleong J. Lexy, Qualitative Research Methods, (Bandung: PT. Risda Karya, 2001), page 105, who said that "as normative science, legal science has a unique way of working 'sui generis' (legal science is a science that has its own character) in helping solve legal problems
} 
reconstruction qualifications related to the obligation to distribute salary from ex-husband who works as civil servant to ex-wife after divorce, is processed through the analysis of legal materials with teleological interpretations.

\section{Results and Discussion}

\subsection{Legal Justice Perspective}

The main legal objective is to realize justice. Justice is the basis of the purpose of law which must be put into all dimensions of a law. Related to the provisions on the obligation to distribute salary from ex-husband who works as civil servant to ex-wife after divorce until she gets married again, is considered unfair and discriminatory. If the divorce occurs at the behest of the husband who works as a civil servant, there is an obligation to distribute salary with his ex-wife until she gets married again. This provision is contained in Government Regulation No. 10 of 1983 concerning Permit for Marriage and Divorce in which Article 8 determines as follows:

a. "If the divorce occurs at the behest of the husband who works as civil servant, he is obliged to distribute a portion of his salary for the living expenses of his ex-wife and children.

b. The distribution of salary as referred to in paragraph (1) consists of one third for the civil servant husband, one third for his ex-wife and one third for his child or children.

c. If the marriage does not produce children, then the portion of the salary that the civil servant husband must give to his ex-wife is half of his salary.

d. If the divorce occurs at the behest of the wife, she does not have rights to the salary portion of her ex-husband.

e. The provision referred to in paragraph (4) does not apply if the wife asks for divorce because she is cheated by her husband.

f. If the ex-wife of the concerned civil servant husband gets married again, her rights to the portion of her salary from her ex-husband are deleted starting from the time she gets married again."

Meanwhile, if the divorce occurs at the behest of the husband who works not as civil servant, he is only obliged to give proper nafkah mut'ah to his ex-wife in the form of money or goods except qobla al dukhul with the ex-wife and provide nafkah, maskan, and kiswah to the ex-wife during the iddah unless the ex-wife has been given talaq ba'in or that she is nusyuz and is not pregnant, and pay off the dowry that is still owed fully, and pay it off half if it is qobla al dukhul. This provision is stated in Islamic Law which has become a positive law in Article 149 Compilation of Islamic Law, as follows:

"If the marriage ends because of divorce, then the ex-husband is obliged to:

a. give proper nafkah mut'ah to his ex-wife in the form of money or goods except qobla al dukhul with the exwife;

b. provide nafkah, maskan, and kiswah to the ex-wife during the iddah unless the ex-wife has been given talaq ba'in or that she is nusyuz and is not pregnant;

c. pay off the dowry that is still owed fully, and pay it off half if it is qobla al dukhul;

d. provide nafkah hadhanah (childcare costs) for children who have not reached the age of 21 (twenty-one) years." 2

Based on the above description, there is a dualism in the provisions of the legislation apply in the Unitary State of the Republic of Indonesia which regulates the consequences of divorce on the obligation of ex-husband to ex-wife. First is the provision intended for the ex-husband who works as civil servant who is obliged to distribute the salary until the ex-wife gets married again and to fulfill other obligations, such as paying nafkah mut'ah, nafkah iddah, and nafkah hadhanah. Second is the provision intended for ex-husband who works not as civil servant who is obliged to pay nafkah mut'ah, nafkah iddah, and nafkah hadhanah.

The provision regarding the arrangement of obligation to distribute salary from ex-husband who works as civil servant to ex-wife after divorce until she gets married again, is considered unfair. It is because marriage and marital ties are over, but the ex-husband still has to give his salary to his ex-wife until his ex-wife gets married again. Satjipto Rahardjo believes that it cannot be called a law if it does not provide justice. Law actually aims to realize a sense of justice. To achieve this goal, the law must be fulfilled and realized to the fullest. ${ }^{3}$

Basically, the purpose of the law is to uphold justice in all aspects of life, so that it can create order and peace in people's lives. Justice must be felt by the ex-husband and ex-wife, so that it reaches balance and not partial justice. However, in the regulation, only ex-wife is protected while ex-husband receives less attention. Thus, in terms of philosophical arrangement for the distribution of salary, from ex-husband who works as civil servant to ex-wife after divorce until she gets married again which is listed in Government Regulation No. 10 of 1983 concerning Marriage and Divorce Permits for Civil Servant jo. Government Regulation No. 45 of 1990, it considered unfair. It is because Government Regulation No. 10 of 1983 concerning Marriage and Divorce Permits

experienced by society".

${ }^{1}$ Association of Laws and Regulations concerning Religious Court, Op.Cit., page 458.

${ }^{2}$ Ibid, page 527.

${ }^{3}$ Satjipto Rahardjo, Law Enforcement: A Sociological Review, (Yogyakarta: Genta Publishing, 2009), page 14. 
for Civil Servant jo. Government Regulation No. 45 of 1990, is actually related to the discipline of civil servant.

\subsection{Legal Certainty Perspective}

3.2.1 The Doctrine of Pure Law (Reine Rechtslehre)

In a brief explanation, Hans Kelsen expresses his desire to cleanse the knowledge of law from elements that are non-legal in nature; for instance, history, morals, sociology, politics and so on. Hans Kelsen refuses if the problems in justice are made part of the discussion in law. According to Hans Kelsen, justice is a rational ideal ideological problem. Kelsen is only willing to accept the law as it is in the form of regulations made and recognized by the state.

\subsubsection{Knowledge on Grundnorm}

Starting from the idea that only recognizes the Law/Statute as the law, Hans Kelsen teaches about groundnorm which is the core parent who gave birth to legal regulations in a particular legal system order.

Groundnorm is likened to fuel which drives the entire legal system. Groundnorm has a function as a basis for why the law must be obeyed and about the implementation of the law that must be accounted for.

3.2.3 Knowledge on Stufenbautheorie

The overall legal regulations are derived from the basic norms that are at the top of pyramid, which are increasingly diverse and spread downward. The top basic norms are abstract and more concrete at downward. Therefore, in the process, what was originally a thing, turned out to be something that could be carried out.

Thus, for the positivists, the law is defined as follows:

a. The law is a set of commands.

b. The law is made by the highest authority (state).

c. The law is aimed at citizens.

d. The law applies locally (in the jurisdiction of the country of manufacture).

e. The law must be separated from morality.

f. There are always external sanctions for lawbreakers.

The advantages of legislation compared to other norms are as follows:

a. The high level of probability. This is related to the prospective nature of legislation; i.e. the rules are aimed at the future. Therefore, it must be able to fulfill the requirements so that people know what matter or what behavior that the legislation expects from them in the future, not the past. Laws and regulations are always required to tell in advance what things are expected to be carried out or not by society. Legal principles, such as 'principles do not apply retroactively', provide assurance that such advantages can be carried out.

b. Unless certainty is more directed at the above formal form, the legislation also provides certainty about the value at stake. Once regulations are made, the value to be protected is also certain by the regulation. Therefore, people should no longer debate whether the value is acceptable or not. ${ }^{1}$

The weaknesses of the legal positivism are:

a. It teaches that law is a common science of the social environment. In fact, the fact is that the law will be very influential and also influenced by its social environment. The social conditions in which the law is located will provide color for the operation of law in society.

b. The positivism approach leads to the trivialization of the concepts of rights and justice.

c. It is a mistake for the positivism approach if it ignores the reality of absolute morality which often becomes the guideline of society. Public confidence, to what should be, has become a strong stimulus for change.

\subsection{Legal Use Perspective}

Law is a number of definitions of knowledge that are set to regulate human behavior traffic. As a common knowledge like other knowledge, law is not born in a vacuum. It was born based on the flow of human communication to anticipate or be a solution to the occurrence of stagnation caused by negative potentials that exist in humans. The use of law needs to be considered because everyone expects the benefits of existing laws and regulations. Ethical flow can be considered an ideal moral teaching or theoretical moral teaching. On the contrary, there is a flow that can be included in practical moral teachings; that is flow utilitarianism. Followers of utilitarianism assume that the purpose of the law is merely to provide as much benefit or happiness as possible for as many people as possible. The handling is based on the social philosophy that every citizen looking for happiness and law is one of the tools. Utilitarian figures include Jeremy Bentham, Jamis Mill and John Stuart Mill. ${ }^{2}$

Jeremy Bentham taught utilitarianism in his famous book "The Theory of Legislation" and "The Principles of Moral and Legislation". The famous doctrine of the teachings is that the law must provide the greatest happiness to the public (the greatest happiness for the greatest number). ${ }^{3}$

Bentham argues that the existence of state and law is solely for the sake of true benefit; i.e. the happiness of

\footnotetext{
${ }^{1}$ Algra \& Duyyendijk, in Satjipto Rahardjo, Op.Cit., page 84-85.

${ }^{2}$ Achmad Ali, Revealing the Curtain of Law (A Philosophical and Sociological Study), (Jakarta: Chandra Pratama, 1996), page 87.

${ }^{3}$ Mukti Fajar ND, Yulianto Achmad, Dualism of Normative and Empirical Law Research, Yogyakarta: Pustaka Pelajar, 2010), page 13-14.
} 
the majority of the people.

It is considered less appropriate if the establishment of a law and regulation actually causes public unrest. Sometimes, legislation is imperfect and not aspirational with people's lives. Thus, it sometimes prioritizes legal certainty and forgets expediency; for example, arrangement of obligation to distribute salary from ex-husband who works as civil servant to ex-wife after divorce until she gets married again (vide Article 8 Government Regulation No. 10 of 1983 concerning Marriage Permits and Divorce for Civil Servant jo. Government Regulation No. 45 of 1990. For ex-wife, this regulation is very useful but on the contrary for ex-husband it is very burdensome, because the ex-husband also has the right to form a new family and needed a living too. So, the law would not be implemented effectively as it should be. The law must protect both parties equally between the ex-wife and exhusband.

\subsection{Islamic Law Perspective}

If a divorce occurs at the behest of a husband who works as a civil servant and in his marriage produces children, then, the ex-husband is obliged to give a third of his salary to his ex-wife and another third to his children. If the marriage does not produce children, then the ex-husband is obliged to give part of his salary to his ex-wife until she gets married again. This provision is contrary to Islamic Law even though the validity of Islamic Law in Indonesia for Muslims is guaranteed constitutionally. Article 29 paragraph (1) of the State Constitution of the Republic of Indonesia of the Republic of Indonesia 1945 states: "The State is based on the One Supreme God." According to Hazairin, the basic norms or fundamental rules mentioned in the Article are: First, it should not enforce or may not apply something that is contrary to the rules of Islam for Muslims, or contrary to the rules of Christianity for Christians, or which contradicts the Balinese Hindu rules for Balinese Hindus or which contradicts Buddhist principles for Buddhists in the State of the Republic of Indonesia. It means that the State of the Republic of Indonesia must not enforce or force and/or create laws that are contrary to religious legal norms and the norms of Indonesian morality originating from or based on the fundamental rules of the One Supreme God. Second, the Republic of Indonesia is obliged to carry out Islamic Law for people who are Muslim, Christian law for people who are Christians, Balinese Hindu law for Balinese Hindus, Buddhist law for Buddhists who exercise their respective laws the religion requires mediation of state power. The meaning of the second interpretation is that the State of the Republic of Indonesia must carry out, in a sense, provide conducive facilities and conditions so that the law originating from a religion embraced by the Indonesian nation can be carried out as long as the implementation of the religious law requires the assistance of state power. It means that state administrators are obliged to carry out the religious law embraced by the Indonesian people for the interests of the followers of the religion concerned. Laws originating from the Islamic religion, for instance, do not only contain the laws of prayer, fasting, zakat, and pilgrimage, but also contain the worldly laws (muamalah) which regulate human relations with humans in society and things; for example, marriage law, inheritance law, waqf law and others. Third, there is a religious law that does not require the help of state power to carry it out, because it can be carried out by the followers of the religion concerned, so that it is the personal obligation of to carry it out according to the demands of their respective religions. It means that the law originates from a religion is recognized in the State of the Republic of Indonesia which can be carried out by each individual of the religion concerned, such as laws relating to pure worship; i.e. law which generally regulates human relations with God Almighty. Regarding to that matter, let the followers of these religion carry it out according to the beliefs of each religion. ${ }^{2}$

Based on the description of Hazairin's interpretation of Article 29 paragraph (1) of the 1945 Constitution of the Republic of Indonesia, it is concluded as follows:

a. In the Unitary State of the Republic of Indonesia, it is not permissible to enforce or apply laws that are contrary to the religious legal norms recognized in Indonesia originating from or based on the fundamental rules of the One Supreme God.

b. The Unitary State of the Republic of Indonesia is obliged to implement the law according to each religion recognized in Indonesia, in the sense of providing facilities and infrastructure and creating situation and conditions conducive to adherents of each religion if they need assistance or intercession of the state power apparatus.

c. The Unitary State of the Republic of Indonesia allows adherents of each religion to implement laws originating from religious legal norms originating from or based on the fundamental rules of the One Supreme God if they do not need assistance or intercession of the state power apparatus to implement them; because it can be carried out by the adherents of each religion and is a personal obligation of the followers of each religion to carry it out according to the guidelines of their respective religious legal norms.

The right of religious freedom is stated more explicitly in Article 29 paragraph (2) of the 1945 Constitution

\footnotetext{
${ }^{1}$ Ibid, page 23 .

${ }^{2}$ Hazairin, Pancasila Democracy, (Jakarta: Bina Aksara, 1981), page 30. Hazairin's interpretation of Article 29 paragraph (2) of the 1945 Constitution was also quoted by Mohammad Daud Ali, Principles of Islamic Law (Islamic Law I), Introduction to Legal Studies and Legal System in Indonesia, (Jakarta: Rajawali Press, 1991), page 234-235.
} 
of the Republic of Indonesia which states: "The State guarantees the independence of each resident to embrace their respective religion and to worship according to their religion and belief".

Based on the aforementioned provisions, the Unitary State of the Republic of Indonesia has the constitutional right to regulate certain laws based on religious law recognized in the State of Indonesia.

According to Abdul Gani Abdullah, applicable laws in Indonesia contain transcendental and horizontal dimensions. Law in the transcendental dimension is closely related to the substance and practice of the first principle of Pancasila, namely the One Supreme God in Article 29 of the 1945 Constitution of the Republic of Indonesia, while law in the horizontal dimension is a rule of life governing the relationship of human life (van het ordening sociale leven $)^{2}$

Pancasila as the basis and philosophy of the Indonesian state which is predominantly Muslim, brings the consequence that Indonesian law must remain consistent with and based on the values of the One Supreme God (which illuminates other precepts) and does not neglect Islamic law.

According to Moh. Mahfud MD., ${ }^{3}$ Indonesia which is based on Pancasila is a nation-state that is religious (religious nation-state), and not a secular state (with no religion). Indonesia is a religious nation-state that applies religious teachings as the moral basis and legal source of knowledge in the administration of the state and the lives of its people. In the field of law, the state of Pancasila outlines four national legal guiding principles which include:

a. Laws in Indonesia must guarantee the integration and integrity of the nation, so that there should be no discriminatory laws based on primordial ties. The point is that national law must maintain the integrity of the nation and state in terms of territory and ideologically.

b. Law must be created democratically and nomocratically based on wisdom. The making must absorb and involve the aspirations of the people and be carried out legally or procedurally and fairly. Making and enforcing the law is not enough to only use democracy based on the majority of votes, but also must be in accordance with the underlying philosophy or rechtsidee.

c. The law must encourage the creation of social justice, which, among others, is characterized by efforts to narrow the gap between the strong and the weak or between the rich and the poor with special protection by the state against weak groups by not allowing them to compete freely.

d. There must be no public law (which binds communities that has diverse primordial ties) based on certain religious teachings, because the state of Pancasila law requires the appearance of laws that guarantee the tolerance of civilized religious life.

In such a conception, Islamic sharia can be a source of law with other long-lived sources as a legal awareness of Indonesian society. Islamic law in the field of civilization concerning family law, still applies to Muslims as it has been made legal politics by the Dutch colonial government since 1848 as long as Muslims want to enforce these rules for themselves. Regarding the enactment of Islamic civil law, Indonesia continued the legal policy of the Dutch East Indies government based on the Transitional Rules of Article I of the 1945 Constitution of the Republic of Indonesia which stipulates that "all existing laws and regulations remain valid as long as the new law has not been held This State of the Republic of Indonesia. "

Moh. Mahfud MD., also explained that Islamic law is a source of national law along with western law, customary law, and other laws. That means that it does not have to be a formal law with its own exclusive form, except its nature to serve (not to impose imperatively) on what has been applied as awareness in everyday life. In this case, the source of law must be interpreted as a source of material law in the sense of being a content material for formal legal sources. However, it needs to be understood that the national legal system is a legal system that is not based on Islam alone, but it also gives a place to other religions adopted by the people to become or provide sources or materials for national legal products. Islamic law cannot be exclusively a separate source of formal law, except for matters of a nature of service relating to pure (mahdhah) worship; for instance, organizing hajj, zakat and others. The state surely cannot require the enactment of certain religious laws, but the state is obliged to serve and protect legally for those who want to carry out their religious teachings with their own awareness. So, there must be no obstacles to Muslims who want to implement Islamic marriage laws within the state. Based on the political aspects of Islamic law in the Indonesian national legal system, Islamic marriage law still has a strong foundation as a living and valid law and has a judicial body if a dispute arises from it. ${ }^{4}$

The position of Islamic law in Indonesian constitution according to Ismail Suny is divided into two periods consisting of:

a. Period of acceptance of Islamic law as a persuasive source

A persuasive source in constitutional law means a source that people must be sure of and accept. By the implementation of the proclamation of the Independence of August 17, 1945 and the enactment of the 1945 Constitution of the Republic of Indonesia, the reception theory lost its legal basis. Since the legal basis of reception

\footnotetext{
${ }^{1}$ Association of Laws and Regulations concerning Religious Court, Op.Cit., page 23.

${ }^{2}$ Abdul Gani Abdullah, Loc.Cit., page 11.

${ }^{3}$ Moh. Mahfud MD., Politics of Islamic Law in the National Legal System, Varia Peradilan No. 290, Januari 2010, page 24

${ }^{4}$ Moh. Mahfud MD., Op.Cit., page 26-27.
} 
theory is the IS (Indische Staatsregeling), after the enactment of the 1945 Constitution of the Republic of Indonesia, IS was no longer valid. This is based on the provisions of Article I of the 1945 Constitution of the Republic of Indonesia concerning the decisive Transitional Rules: "All existing legislations remain valid as long as they have not been replaced by new legislation according to this Constitution." However, the basis the law, which is stipulated by the 1945 Constitution of the Republic of Indonesia which is no longer valid, cannot be used as a legal basis. After the enactment of the 1945 Constitution of the Republic of Indonesia, Islamic law applies to the Indonesian people who are Muslim because of the position of Islamic law itself, not because that Islamic law has been accepted by customary law. Article 29 of the 1945 Constitution of the Republic of Indonesia determines: "(1) The State is based on the One Supreme God (2) The State guarantees the independence of each resident to embrace his/her own religion and worship according to his/her religion and belief."

b. Period of acceptance of Islamic law as an authoritative source

Authoritative sources according to constitutional law are sources that have authority. After the inclusion of Piagam Jakarta (the Jakarta Charter) in the Decree of the President of the Republic of Indonesia on July 5, 1959, the Jakarta Charter or acceptance of Islamic law became a source of authoritative law in Indonesian state law, not just a persuasive source. ${ }^{1}$

According to Muhammad Tahir Azhary, Islamic law in Indonesia applies with the following reasons:

a. Normatively, it is part of Islamic law that has social sanctions when the law is violated. Especially Islamic law which regulates human relations with God. Implementation of compliance with Islamic law that applies normatively in the society, will depend on the awareness of the faith of the Muslims themselves, where the implementation is also left to the conviction of the person concerned.

b. In formal juridical terms, it is a part of Islamic law that regulates human relations and regulates the relationship between humans and other creatures, based on or because it is appointed by legislation; for instance, Islamic marriage law based on Article 2 paragraph (1) of Law Number 1 of 1974, concerning Marriage. ${ }^{2}$

Based on this description, the existence of Islamic law from the Dutch colonial administration to the present (reformation era) has experienced rapid development and has become a source of national law along with western law, customary law, and other laws.

According to M. Irfan Idris, the existence of Islamic law in Indonesia has experienced rapid development since the days of the sultanate to this day (post the New Order). In the history of the course of law in Indonesia, the presence of Islamic law in national law is a struggle for existence. The existence theory formulates the state of Indonesian national law in the past, present, and future, that Islamic law is in Indonesian national law, in written and unwritten law, in various fields of legal life and legal practice. The existence theory, in relation to Islamic law, is a theory that explains the existence of Islamic law in Indonesian national law; in a sense as part of Indonesian national law. Islamic law is in national law and Islamic legal norms which function as the national legal materials for Indonesian people. Therefore, the existence of Islamic law in national law is a sub system of the national legal system. Therefore, Islamic law also has the opportunity to contribute to the establishment and renewal of national law, although it must be recognized that the legal uncertainty of legal trichotomy is not over yet. ${ }^{3}$

Regarding the existence of the existence theory of Islamic law in national law, Ichtijanto revealed that the form of the existence of Islamic law in Indonesian national law is: existence in a sense as an integral part of Indonesian national law. Existence in the sense of independence, strength and authority recognized by national law and given status as national law. Existence in national law in the sense of Islamic legal norms serves as a filter for Indonesian national legal materials. Existence in the sense as the main material and the main element of Indonesian national law. ${ }^{4}$

Thus, based on the description above, the existence of Islamic law in national law in existence is a sub-system of the national legal system and as a source of law other than Western law and Customary law.

Islamic law is one of several religious laws which is a source of divorce law which is recognized as legal in Indonesia. This is confirmed in Article 37 of Law No. 1 of 1974 concerning Marriage, which determines: "If the marriage is terminated due to divorce, the community property are regulated according to their respective laws" and this provision is also relevant to the provisions of Article 2 paragraph (1) Law No. 1 of 1974, which determines: "Marriage is legal, if it is carried out according to the law of each religion and its beliefs". Based on this provision,

\footnotetext{
${ }^{1}$ Ismail Suny, “Position of Islamic Law in the Indonesian State Administration System” in Amrullah Ahmad, et al (ed), Dimensions of Islamic Law in the National Legal System, Remembering 65 years Prof. Dr. H. Bustanul Arifin, S.H., (Jakarta: Gema Insani Press, 1996), page 133-135.

${ }^{2}$ Muhammad Tahir Azhary, State of Law, A Study of Its Principles from the Aspect of Islamic Law, Its Implementation in the Medina and Present Period of the Country, (Jakarta: Kencana, 2003), page 220.

${ }^{3}$ M. Irfan Idris, Constitutionalization of Islamic Law in National Law, Constitution Journal, Vol. 3 No. 2, (Jakarta: Constitutional Court of the Republic of Indonesia, May 2000), page 142-143. Furthermore, M. Irfan Idris explained that what is meant by legal trichotomy is that Indonesia recognizes the existence of three types of laws that apply in national law which include Islamic law, western law and customary law. The enactment of these three types of law, in positive law, is one of the causes of legal uncertainty in the rule of law; what needs to be considered is the way to unification and codify the law.

${ }^{4}$ Ichtijanto, Development of the Theory of the Applicability of Islamic Law in Indonesia, (Bandung: Remaja Rosdakarya, 1994$)$, page 137.
} 
what determines the legitimate of marriage is based on their respective religious law. Therefore, Indonesian citizens who are Muslim and want to do marriage, it must be carried out according to Islamic marriage law norms so that it is legitimate. Moreover, based on these provisions, with widespread interpretation, it was concluded that Indonesian citizens who are Muslims and want to end the marriage in divorce, it must be carried out according to Islamic marriage law norms so that they are legitimate.

Based on these provisions and strengthened by the enactment of Law No. 7 of 1989 concerning the Religious

Courts, it contains the following legal implications:

a. Islamic law is a source of marriage and divorce law for Muslims.

b. Islamic law has the same position with customary law and western law (specifically Burgerlijk Wetboek/ Civil Code, as a source that sustains national law.

c. The Unitary State of the Republic of Indonesia can regulate a matter of marriage and divorce law for every Indonesian Muslim citizen based on Islamic law; as long as the legal arrangements for marriage and divorce are to meet legal requirements for Indonesian Muslims.

\section{Conclusion}

Arrangement of obligation to distribute salary from ex-husband who works as civil servant to ex-wife after divorce until she gets married again as stated in Article 8 of Government Regulation No. 10 of 1983 jo. Government Regulation 45 of 1990, determines the following:

a. "If the divorce occurs at the behest of the husband who works as civil servant, he is obliged to distribute a portion of his salary for the living expenses of his ex-wife and children.

b. The distribution of salary as referred to in paragraph (1) consists of one third for the civil servant husband, one third for his ex-wife and one third for his child or children.

c. If the marriage does not produce children, then the portion of the salary that the civil servant husband must give to his ex-wife is half of his salary.

d. If the divorce occurs at the behest of the wife, she does not have rights to the salary portion of her ex-husband.

e. The provision referred to in paragraph (4) does not apply if the wife asks for divorce because she is cheated by her husband.

f. If the ex-wife of the concerned civil servant husband gets married again, her rights to the portion of her salary from her ex-husband are deleted starting from the time she gets married again."

It is reconstructed into:

a. If the divorce occurs at the behest of the civil servant husband, he is obliged to provide livelihood costs to the ex-wife according to his ability which are paid when the decision obtains permanent legal force; meanwhile, a Muslim civil servant husband is obliged to provide nafkah mut'ah that includes the cost of livelihood to the ex-wife and nafkah iddah at the witnessing of the divorce pledge in accordance with his ability.

b. If the divorce occurs at the behest of the wife, the husband is not obliged to give a living expense to the exwife.

\section{References}

Ali, A. (1996). Revealing the Curtain of Law (A Philosophical and Sociological Study). Jakarta: Chandra Pratama.

Association of Laws and Regulations concerning Religious Court. (2010). Supreme Court of the Republic of Indonesia, Directorate General of Religious Court. Jakarta.

Azhary, M. T. (2003). State of Law, A Study of Its Principles from the Aspect of Islamic Law, Its Implementation in the Medina and Present Period of the Country. Jakarta: Kencana.

Champbell, E., et al. (1996). Legal Research. Sydney: The Law Book Company Ltd.

Editorial Board of the Encyclopedia of Islam. (1997). Encyclopedia of Islam 4th Print Part 4. Jakarta: Ichtiar Baru Van Hoeve.

Hazairin. (1981). Pancasila Democracy. Jakarta: Bina Aksara.

Ichtijanto. (1994). Development of the Theory of the Applicability of Islamic Law in Indonesia. Bandung: Remaja Rosdakarya.

Idris, M. I. (2000). Constitutionalization of Islamic Law in National Law, Constitution Journal, 3(2), 142-143.

Mahfud, M.M.D. (2010). Politics of Islamic Law in the National Legal System. Varia Peradilan No. 290.

Marzuki, P. M. (2008). Legal Research. Jakarta: Prenada Media.

Moleong, J. L. (2001). Qualitative Research Methods. Bandung: PT. Rosda Karya.

Mukti, F. N. D., Achmad, Y. (2010). Dualism of Normative and Empirical Law Research. Yogyakarta: Pustaka Pelajar.

Rahardjo, S. (2009). Law Enforcement: A Sociological Review. Yogyakarta: Genta Publishing.

Sidarta, B. A. (2009). Normative Legal Research: Philosophical and Documentary Research Analysis, in Legal Research Book: Constellation and Reflection. Jakarta: Yayasan Obor Indonesia.

Sumardjono, M. S. W. (2001). Guidelines for Making Research Proposals: A Basic Guide. Jakarta: Gramedia 
Pustaka Utama.

Suny, I. (1996). Position of Islamic Law in the Indonesian State Administration System. in Amrullah Ahmad, et al (ed), Dimensions of Islamic Law in the National Legal System, Remembering 65 years Prof. Dr. H. Bustanul Arifin, S.H. Jakarta: Gema Insani .

Wignyosubroto, S. (n.d). An Introduction to the Discussion on the Development of Legal Research in Long-Term Development Phase II. Jakarta: National Law Development Agency of the Department of Justice. 